\title{
HUBUNGAN ANTARA PENGETAHUAN DAN SIKAP PADA REMAJA PUTRI TENTANG FLUOR ALBUS
}

\author{
Nurulicha*Awis Hamid Dani**
}

\begin{abstract}
ABSTRAK
Fluor albus atau keputihan dapat mengenai sebagian besar wanita termasuk di dalamnya keputihan yang dapat mengenai remaja putri.Hal ini terkait dengan pengetahuan remaja tentang fluor albus. Tujuan dalam penelitian ini adalah untuk mengetahui hubungan antara pengetahuan dengan sikap remaja putri tentang fluor albus di MTS Al-Ittihad Tanjungsari Bogor. Metode yang digunakan dalam penelitian ini adalah metode analitik dengan pendekatan cross sectional. Data yang digunakan adalah data primer dengan instrumen penelitian adalah kuesioner yang disebarkan pada 81 responden di kelas 1, 2 dan 3diambil dengan metode angket. Analisis data untuk pengujian hipotesis menggunakan uji Chi square. Hasil penelitian menunjukan pengetahuan tentang fluor albus pada remaja putri dengan pengetahuan kurang sebesar $35,80 \%$, sedangkan untuk remaja putri yang memiliki sikap negatif sebesar 43,21\%. Terdapat hubungan yang bermakna antara pengetahuan dengan sikap remaja putri tentang fluor albus di MTS Al-Ittihad Tanjungsari Bogor. Simpulan dari penelitian ini bahwa terdapat hubungan yang bermakna $(\mathrm{p}<0,05)$ yaitu pengetahuan yang kurang yang akan menyebabkan sikap negatif tentang fluor albus pada remaja putri di MTS Al-Ittihad Tanjungsari Bogor.
\end{abstract}

Kata kunci : pengetahuan, sikap, fluor albus.

\begin{abstract}
Fluor albus affect the majority of women include adolescence. This problem related to lack of knowledge about fluor albus. The purpose of this research is to investigate the relationship between knowledge and attitude about the fluor albus of adolescence in Senior High School IttihadTanjungsari Bogor. Method used in this research is the analytical method with cross sectional approach. The data used are primary data with the research instrument was the questionnaire distributed in 81 respondents in grades 1, 2 and 3 Senior High School. Research shows that knowledge of the fluor albus in adolescence with less knowledge is $35.80 \%$, while for adolescencewho have negative attitude is $43.21 \%$. There is a significant relationship between knowledge and attitude of adolescence about the fluor albus in Senior High School Ittihad Tanjungsari Bogor. The conclusions from this research therewas a significant correlation( $\mathrm{p}<0.05)$, that lackof knowledgewilllead tonegative attitudesaboutfluoralbusin adolescenceatSenior High School1Ittihad Tanjungsari bogor
\end{abstract}

Key words: knowledge, attitudes, fluor albus.

\footnotetext{
*Staf Pengajar Program Studi D3 Kebidanan STIKes Cirebon

**Staf Pengajar Program Studi Bahasa Inggri STBA Cirebon
} 


\section{PENDAHULUAN}

Tujuan pembangunan kesehatan di Indonesia diarahkan untuk lebih meningkatkan derajat kesehatan dan kualitas sumber daya manusia.Mortalitas dan morbiditas wanita di Indonesia masih merupakan masalah besar yang terjadi di Indonesia. Masalah besar tersebut akan menghambat pembangunan kesehatan di Indonesia yang nantinya akan mempengaruhi kehidupan bangsa Indonesia terhadap pendidikan, pelayanan kesehatan, lapangan pekerjaan, sosial ekonomi dan lingkungan hidup. ${ }^{1}$

Sesuai dari hasil konferensi internasional populasi dan pembangunan (ICPD) di Kairo tahun 1994 bahwa kesehatan reproduksi sebagai suatu keadaan utuh kesejahteraan fisik, mental dan sosial dan tidak semata-mata karena tidak ada penyakit atau gangguan dalam semua hal yang berhubungan dengan sistem reproduksi serta fungsi dan prosesnya. Seperti yang telah dikatakan dalam hasil ICPD memuat juga tentang cangkupan kesehatan reproduksi dalam konteks pendekatan siklus hidup yakni kesehatan ibu dan bayi baru lahir, keluarga berencana, pencegahan dan penanganan penyakit menular seksual (PMS)/Humman Immununo Deficiency Virus (HIV)/Acquired Immununo Deficiency Syndrom (AIDS), kesehatan reproduksi remaja, dan lain-lain. Untuk mencpai tujuan cangkupan kesehatan reproduksi tersebut, ICPD membuat program utama yang salah satunya adalah paket kesehatan reproduksi dasar melalui program safe motherhood, keluarga berencana, PMS dan kesehatan reproduksi remaja. $^{2}$

Fluor albus atau keputihan merupakan istilah bagi keluarnya cairan yang berlebihan dari jalan lahir / vagina selain darah menstruasi.Fluor albus ini merupakan keluhan yang umum terjadi pada wanita di dunia, terutama di wilayah Asia. Hampir sebagian besar wanita pernah mengalami fluor albus. Menurut studi badan kesehatan dunia (WHO) sebanyak $75 \%$ wanita di seluruh dunia setidaknya pernah mengalami candidiasis atau keputihan sebanyak satu kali dalam seumur hidupnya dan $45 \%$ diantaranya mengalaminya dua kali atau lebih. Hal ini mungkin dikarenakan kurangnya pengetahuan dan informasi tentang fluor albus yang didapatkan tidak akurat atau bahkan tidak dapat dipertanggung jawabkan, juga mungkin dikarenakan masih adanya mitos yang beredar di masyarakat tentang fluor albus terutama pada remaja putri yang baru mulai memahami organ reproduksinya. Sebagian besar wanita Indonesia mempunyai potensi untuk terserang keputihan, termasuk di dalamnya keputihan dapat menyerang remaja putri. ${ }^{3,4}$

Dampak dari fluor albus atau keputihan yang terlambat atau tidak diobati dapat berakibat buruk bagi kehidupan seorang wanita. Kasus PMS khususnya klamidia terjadi sekitar 6,2\% pada remaja usia 15-24 tahun. Sebagian besar infeksi saluran Chlamydia tracomatis genitourinary pada wanita adalah asimptomatik.Infeksi dapat mengakibatkan komplikasi yang signifikan secara jangka panjang termasuk infertilitas, kehamilan ektopik dan nyeri panggul kronis serta dapat terjadinya HIV. Faktor - faktor yang dapat meningkatkan terjadinya penyakit ini adalah lingkungan, gaya hidup dan kebersihan diri. ${ }^{5}$

Berdasarkan hasil pengamatan langsung yang dilakukan di puskesmas Bohgor terdapat beberapa remaja putri yang mengeluh keputihan dan berdasarkan hasil dari pembicaraan langsung pada remaja putri yang ada di MTS Al-Ittihad Tanjungsari Bogor tahun 2015 terdapat kesan bahwa sebagian besar remaja putri kurang memahami mengenai kesehatan reproduksi secara umum dan khususnya mengenai fluor albus.

Tujuan dalam penelitian ini adalah untuk mengetahui Hubungan Antara Pengetahuan Dengan Sikap Remaja Putri Tentang Fluor Albus Di MTS Al-Ittihad Tanjungsari Bogor.

\section{METODE PENELITIAN}

Penelitian ini menggunakan metode analitik dengan pendekatan cross sectional yaitu jenis penelitian yang dilakukan terhadap variabel yang diteliti dengan membuat perbandingan atau menghubungkan variabel yang lain, dengan tujuan mengetahui hubungan antara pengetahuan 
dengan sikap remaja putri tentang fluor albus di MTS Al-Ittihad Tanjungsari Bogor, Populasi dalam penelitian ini adalah seluruh siswi MTS Al-Ittihad Tanjungsari Bogor yaitu kelas 1, kelas 2, dan kelas 3.Sampel penelitian ini diambil dengan menggunakan metode stratified random sampling pada populasi baik kelas 1, kelas 2 maupun kelas 3 diperoleh 86 untuk sampel.

Data yang digunakan oleh penulis adalah data primer, yaitu data yang diperoleh langsung dari responden melalui kuesioner yaitu cara pengumpulan data dengan mengedarkan suatu daftar pertanyaan yang berupa formulir yang berisikan pertanyaan berbentuk pilihan jawaban, dimana jawabannya telah disediakan. ${ }^{6}$

Pengolahan data pada penelitian ini setelah data terkumpul, prosesnya adalah mencocokan data dari kuesioner yang berisi pertanyaan. Setelah data dicocokan, pengolahan data dapat dilakukan melalui editing, coding, processing, Cleaning,

Untuk analisis data digunakan analisis data univariat dan analisis data bivariat. Analisis data univariat digunakan untuk melihat presentasi dari variabel yang diteliti dan dalam pengajuannya analisa univariat ini dalam bentuk tabel distribusi frekuensi, Tahap analisa berikutnya adalah dengan menggunakan uji statistik bivariat untuk melihat hubungan variabel independen dan variabel dependen. Pada penelitian melakukan analisa data kategori, dengan demikian pengujian menggunakan rumus Chi-Square.

\section{HASIL PENELITIAN}

\section{Pengetahuan}

Tabel 1 Distribusi frekuensi pengetahuan remaja putri tentang Fluor Albus

\begin{tabular}{lcc}
\hline Pengetahuan & Frekuensi & $\%$ \\
\hline Baik & 17 & 20,99 \\
Cukup & 35 & 43,21 \\
Kurang & 29 & 35,80 \\
\hline Total & 81 & 100,00 \\
\hline
\end{tabular}

Dari tabel 1 remaja putri yang mempunyai pengetahuan kurang tentang fluor albus di MTS yaitu sebanyak 29 orang $(35,80 \%)$.

\section{Sikap}

Tabel 2 Distribusi frekuensi sikap remaja putri tentang Fluor Albus

\begin{tabular}{lcc}
\hline Sikap & Frekuensi & $\%$ \\
\hline Positif & 46 & 56,79 \\
Negatif & 35 & 43,21 \\
\hline Total & 81 & 100 \\
\hline
\end{tabular}

Dari tabel 2 remaja putri di MTS Al-Ittihad Bogormempunyai sikap negatif yaitu sebanyak 35 orang $(43,21 \%)$. 


\section{Hubungan Pengetahuan dengan Sikap Remaja}

Tabel 3 Tabulasi Silang Pengetahuan Dengan Sikap Remaja Putri Tentang Fluor Albus

\begin{tabular}{|c|c|c|c|c|c|c|c|}
\hline \multirow{3}{*}{ Pengetahuan } & \multicolumn{4}{|c|}{ Sikap } & \multirow{3}{*}{ Total } & \multirow{3}{*}{$\%$} & \multirow{3}{*}{ P-Value } \\
\hline & \multicolumn{2}{|c|}{ Positif } & \multicolumn{2}{|c|}{ Negatif } & & & \\
\hline & $\mathrm{F}$ & $\%$ & $\mathrm{~F}$ & $\%$ & & & \\
\hline Baik & 14 & 82.35 & 3 & 17.65 & 17 & 100 & \\
\hline Cukup & 20 & $\begin{array}{l}57.14 \\
4138\end{array}$ & 15 & 42.86 & 35 & 100 & 0,03 \\
\hline Kurang & 12 & & 17 & & 29 & 100 & \\
\hline Total & 46 & 56.79 & 35 & 43,21 & 81 & 100 & \\
\hline
\end{tabular}

Berdasarkan tabel 3 tabulasi silang antara pengetahuan dengan sikap remaja putri tentang fluor albus di MTS Al-Ittihad Bogor dapat dijelaskan sebagai berikut:dari 29 remaja putri di MTS Al-Ittihad yang berpengetahuan kurang diantaranya terdapat 17 orang $(58,62 \%)$ bersikap negatif.

Berdasarkan perhitungan di atas, maka diperoleh hasil perhitungan statistik uji Chikuadrat sebesar 7,34 dan P-value $=0,03$. Oleh karena nilai P-value lebih kecil dibandingkan $5 \%(0,03<0,05)$ maka terdapat hubungan yang bermakna antara pengetahuan dengan sikap remaja putri tentang fluor albus di MTS.

\section{PEMBAHASAN}

\section{Pengetahuan Remaja Putri Tentang Fluor Albus}

Dari hasil penelitian diketahui bahwa remaja putri di MTS Al-Ittihad Bogormempunyai pengetahuan kurang sebanyak 29 orang $(35,80 \%)$. Hasil penelitian ini berbeda dengan penelitian sebelumnya yang dilakukan oleh Fara Imelda di SMA wilayah Bandung timur tahun 2008 yaitu masih ada remaja putri yang pengetahuannya kurang terhadap fluor albus yaitu sebesar 9,51\%, kurangnya pengetahuan pada remaja tersebut dapat disebabkan oleh berbagai hal, diantaranya : Media informasi, Sekolah dan Media masa.

Menurut teori yang ada, pengetahuan adalah merupakan hasil dari tahu dan ini terjadi setelah orang melakukan penginderaan terhadap suatu objek tertentu. Penginderaan terjadi melalui panca indera manusia, yakni indera penglihatan, pendengaran, penciuman, rasa dan raba. Sebagian besar pengetahuan manusia diperoleh melalui mata dan telinga. ${ }^{7}$ Pengetahuan yang dilihat tentang fluor albus mengenai pengertian, klasifikasi, etiologi, dampak serta penanganan dan pencegahan.

Adapun faktor - faktor yang mempengaruhi pengetahuan seseorang antara lain : pertama faktor usia, usia dapat mempengaruhi seseorang dalam kesiapan belajar dan menerima informasi baru. Pada umumnya orang yang masih muda lebih mudah untuk belajar dalam hal mengingat dan menyimpan bahan pelajaran. Kedua faktor pendidikan, dimana pendidikan mempengaruhi proses belajar. Makin tinggi pendidikan seseorang, makin mudah orang tersebut menerima informasi. ${ }^{8}$

Untuk memberikan pendidikan kesehatan reproduksi bagi remaja dapat diberikan disekolah dengan membuka informasi kesehatan reproduksi, melalui penyuluhan secara klasikal dan bimbingan secara individual oleh guru bimbingan dan konseling (BK) sewaktuwaktu bila remaja membutuhkan. Untuk penyuluhan secara klasikal ini, sekolah dapat bekerja sama dengan institusi pendidikan kesehatan, misalnya Politeknik Kesehatan atau Sekolah Tinggi Ilmu Kesehatan. 9,4 


\section{Sikap Remaja Putri Tentang Fluor Albus}

Berdasarkan hasil penelitian di MTS Al-Ittihad Bogorremaja putri yang mempunyai sikap negatif sebanyak 35 orang $(43,21 \%)$. Hasil yang tidak jauh berbeda apabila dibandingkan dengan hasil penelitian yang dilakukan oleh Wahyu Harjani Noer S di SMA Tunas Patria Ungaran pada tahun 2007 sikap negatif remaja putri sebesar $50 \%$.

Hal tersebut dapat terjadi karena banyak faktor yang mempengaruhi terbentunya suatu sikap, salah satunya adalah kurangnya informasi baru mengenai sesuatu hal yang dapat menjadi landasan pengetahuan baru bagi terbentuknya sikap. ${ }^{8}$ Selain itu kurangnya kesadaran pada remaja untuk menentukan kesehatan reproduksi dan kurangnya keterbukaan kepada orang tua atau petugas kesehatan.

Apabila dihubungkan dengan teori, sikap dapat dipengaruhi oleh beberapa hal, pertama adalah media informasi, pada media cetak ataupun media elektronik seharusnya memberikan berita atauinformasi yang faktual dan disampaikan secara objektif, yang cenderung dipengaruhi oleh sikap penulisannya, sehingga dapat berpengaruh terhadap sikap konsumennya. Kedua adalah lembaga pendidikan dan lembaga agama, konsep moral dan ajaran dari lembaga pendidikan dan lembaga agama sangat menentukan sistem kepercayaan sehingga tidak mengherankan jika pada gilirannya konsep tersebut mempengaruhi sikap. ${ }^{8,10}$

Disebutkan pula menurut American Journal of Public HealthSalah satu kemungkinan kurangnya pencegahan terhadap kesehatan reproduksi pada remaja adalah bahwa remaja kemungkinan jarang mencari pelayanan kesehatan karena keterbatasan waktu yang mereka miliki atau karena masih bergantungnya remaja pada oang tua. ${ }^{2}$

\section{Hubungan Pengetahuan Dengan Sikap Remaja Putri Tentang Fluor Albus}

Berdasarkan penelitian yang dilakukan di MTS Al-Ittihad didapatkan hasil bahwa terdapat hubungan yang signifikan antara pengetahuan dengan sikap remaja putri tentang fluor albus. Hal ini dapat dilihat dari tabel 4.3 bahwa dari 29 orang remaja putri yang mempunyai pengetahuan kurang, sebanyak 17 orang $(35,42 \%)$ bersikap negatif terhadap fluor albus.

Apabila dibandingkan dengan hasil penelitian yang dilakukan oleh Wahyu Harjani Noer S di SMA Tunas Patria Ungaran pada tahun 2007 terdapat hubungan yang signifikan antara pengetahuan dengan sikap remaja putri tentang fluor albus yaitu semakin baik pengetahuan maka sikapnya pun akan semakin positif.

Sesuai dengan teori yang menjelaskan bahwa pengetahuan dipengaruhi oleh faktor pendidikan formal. Pengetahuan sangat erat kaitannya dengan pendidikan, dimana diharapkan bahwa dengan pendidikan yang tinggi maka orang tersebut akan semakin luas pula pengetahuannya. Akan tetapi perlu ditekankan, bukan berarti seseorang yang berpendidikan rendah mutlak berpengetahuan rendah pula. Hal ini mengingat bahwa peningkatan pengetahuan tidak mutlak diperoleh dari pendidikan formal saja, akan tetapi dapat diperoleh dari pendidikan non formal. Pengetahuan seseorang tentang suatu objek mengandung dua aspek yaitu aspek positif dan aspek negatif. Kedua aspek ini yang akan menentukan sikap seseorang, semakin banyak aspek positif dari objek yang diketahui, maka akan menimbulkan sikap yang makin positif terhadap objek tertentu.

\section{SIMPULAN}

Hasil penelitian dari hubungan antara pengetahuan dengan sikap remaja putri tentang Fluor Albus di MTS Al-Ittihad, dapat diambil kesimpulan sebagai berikut:

1. Remaja putri di MTS Al-Ittihad mempunyai pengetahuan yang kurang tentang fluor albus sebesar $35,80 \%$.

2. Remaja putri di MTS Al-Ittihad mempunyai sikap yang negatif tentang fluor albus sebesar $43,21 \%$. 
3. Terdapat hubungan yang signifikan antara pengetahuan dengan sikap remaja putri tentang fluor albus di MTS Al-Ittihad

\section{SARAN}

1. Mengingat masih adanya remaja putri yang memiliki pengetahuan kurang maka diharapkan untuk selalu memberikan informasi tentang kesehatan reproduksi khususnya fluor albus baik oleh lembaga pendidikan, orang tua, guru maupun media masa.

2. Mengingat masih adanya remaja putri yang memiliki sikap negatif maka perlu ditingkatkan pemberian informasi oleh guru pada siswi disekolah dan mengikutsertakan peran orang tua dalam pencegahan fluor albus.

3. Mengingat adanya hubungan yang signifikan antara pengetahuan dengan sikap remaja putri tentang fluor albus maka perlu dilakukan peningkatan pengetahuan dengan pendidikan formal maupun non formal sehingga remaja putri terampil dalam pencegahan fluor albus dan membentuk sikap yang positif.

\section{DAFTAR PUSTAKA}

1. Saefuddin BA. Buku Panduan Praktis Pelayanan Kontrasepsi. Jakarta:Bina Pustaka;2003.

2. World Health Organization. Profil Kesehatan Reproduksi Indonesia.Jakarta:Departemen Kesehatan Republik Indonesia;2003.

3. Maharani, Putu Anindita. Jangan anggap enteng keputihan.[diakses tanggal 14 November 2010]. diunduh http://www.farmacia.com.

4. Noer, Wahyu Harjani. Hubungan pengetahuan dan sikap remaja puteri tentang keputihan (flour albus) dengan upaya pencegahannya (Studi pada siswi SMA Tunas Patria Ungaran tahun 2007).[diakses tanggal 14 November 2010].Diunduh dari http://www.fkm.undip.ac.id/

5. Widiyanti, Eko. Hubungan hygiene pribadi keputihan pada siswi sma negeri 1 cepiring kabupaten kendal.[diakses tanggal 17 November 2010].Diunduh dari:http://www.fkm.undip.ac.id/.

6. Riduwan. Belajar Mudah Penelitian Untuk Guru-Karyawan dan Peneliti Pemula.Bandung: Alfabeta;2008.

7. Indarti, Junita. Kesehatan reproduksi wanita. Jakarta: Gramedia Pustaka;2005

8. Notoadmodjo, S. Promosi Kesehatan dan Ilmu Perilaku. Jakarta:Rineka Cipta;2007.

9. Fatrahady, Lalu Buly. Fluor albus (leukorea).[diakses tanggal 17 November 2010]. Diunduh dari: www.fk-unram.ac.id.

10. Kharis. Kesehatan Reproduksi.[diakses tanggal 17 November 2010].Diunduh dari:www.pdpersi.co.id 